\title{
Comparative diagnostic techniques in ruminant Fas- ciolosis: fecal sedimentation, indirect ELISA, liver inspection and serum enzyme activities
}

\author{
Meskerem Adamu ${ }^{1 *}$, Abebe Wossene ${ }^{2}$, Getachew Tilahun ${ }^{3}$ and Asoke Kumar Basu ${ }^{2}$ \\ ${ }^{1}$ Ethiopian Biotechnology Institute, Addis Ababa, Ethiopia \\ ${ }^{2}$ Department of Pathology and Parasitology, Collage of Veterinary Medicine, Addis Ababa Univer- \\ sity, P.O. Box 34, Debre Zeit, Ethiopia \\ ${ }^{3}$ Aklilu Lemma Institute of Pathobiology, Addis Ababa University, Addis Ababa, Ethiopia \\ *Corresponding author: Meskerem Adamu, madchere@gmail.com or mesku12345@yahoo.com
}

\begin{abstract}
Different diagnostic tests have some disadvantages in diagnosing Fasciolosis. A cross-sectional study was conducted to estimate the prevalence and to compare the different diagnostic techniques in ruminant Fasciolosis: ELISA, biochemical analysis, liver and coprological examination. Out of the 324 cattle, 350 sheep and 385 goats slaughtered at Bishoftu, ELFORA Export Abattoir, $125(38.5 \%), 4(1.1 \%)$ and $2(0.5 \%)$ and $108(33 \%) 4(1.1 \%)$ and $2(0.5 \%)$ were found to be positive for lesions of fasciolosis and Fasciola eggs, respectively. The results of different diagnostic techniques in randomly selected 134 cattle, 68 sheep and 22 goats samples were compared. Out of the 134 examined cattle, 100 (75\%) were found to be positive for antibodies against Fasciola specific f2 antigens followed by 54 (41\%) for lesions of Fasciolosis, 40 (30\%) for Fasciola eggs and $56(42 \%)$ and $100(75 \%)$ of the samples had an increased level of serum enzyme GGT and LDH above the normal values, respectively. The overall assessment indicates the test agreement of ELISA findings with the results of fecal examination is weak (Kappa=0.236), ELISA findings with the results of liver lesions is moderate (Kappa $=0.373$ ), liver lesions with GGT determination is moderate (Kappa $=0.332)$ and liver lesions with level of LDH is absent $($ Kappa $=-0.066)$. However, there was a strong relationship (Kappa $=0.758)$ between fecal examination and liver lesions. In small ruminants, the prevalence of Fasciolosis was lower both in coproscopy and indirect ELISA tests: only one out of 68 sheep was positive coproscopically and 3 were positive serologically; and one out of 22 goats tested was positive both at coproscopy and serological examinations. The sensitivity of ELISA was higher compared to the oth-
\end{abstract}


ers techniques in diagnosing ruminant fasciolosis. Coprological examination should be repeated and supported by other diagnostic methods.

Key Words: Coproscopy; ELISA; Fasciola; Liver enzymes; Ruminants

\section{Introduction}

The economic losses due to fasciolosis throughout the world are enormous. In Ethiopia, the prevalence of bovine fasciolosis has been reported to exist in many parts of the country (Abera, 1990; Zewdu, 1991; Abdul, 1992; Rahmeto, 1992). Fasciola hepatica and $F$. gigantica are causing major economic losses in livestock in East Africa (Malone et al., 1998). F. hepatica was shown to be the most important fluke species in Ethiopian livestock with distribution over three quarter of the nation except in the arid north- east and east of the county while the distribution of $F$. gigantica was mainly localized in the western humid zone of the country that encompasses approximately one fourth of the nation (Yilma and Malone, 1998). Diagnosis of Fasciolosis is based on clinical signs, seasonal occurrence, liver and coprological examination, which may be supplemented by two other laboratory tests. The first estimation of plasma levels of enzymes released by damaged liver cells and the second is the detection of antibodies against components of flukes, the ELISA and passive haemoagglutination test being the most reliable (Urquhart et al., 1996). Proper diagnosis of the disease is important in prescribing effective drugs and assists any control programs directed to Fasciolosis. However, the different diagnostic techniques used today to confirm Fasciolosis in ruminants have their limitations. Coprological analysis is still commonly employed to diagnose bovine Fasciolosis despite the overwhelming consensus that this method is not wholly reliable. On the other hand, since weak infections cannot be detected, the animal become the source of new infection (Sanchez-Andrade et al., 1995). The most direct and reliable technique for the diagnosis of Fasciolosis is liver examination at slaughter or necropsy. But using this diagnostic technique it is impossible to detect Fasciolosis in live animals. Serum activities of lactate dehydrogenase (LDH) and gamma glutamyl transferase (GGT) may be used as markers of the different stages of Fasciola infection in sheep, indicating the presence of cell necrosis caused by juvenile migrating flukes and bile duct lesions associated with mature helminthes, respectively (Ferre et al., 1997). Different immunodiagnostic tests have been used in the early immune diagnosis of Fasciolosis, but they have some disadvantages, such as cross-reactions with other trematodes, leading to false positive results (Gonenc et al., 2004). 
The aim of this study was, therefore, to compare the results of different diagnostic techniques for Fasciolosis in slaughtered ruminants at ELFORA Export Abattoir, Bishoftu and to assess the extent of correlation of pathological lesion caused by flukes with the results of enzyme analysis.

\section{Material and methods}

\section{Study area and study population}

Data were collected from ELFORA Export Abattoir found in Bishoftu. Study animals were ruminants (cattle, sheep and goats). Animals were purchased from different parts of the country and brought to the abattoir. According to the information taken from the abattoir, sheep and goats were purchased from the arid eastern part of the country. Slaughtered animals were usually between 1 and 4 years of age for sheep and goats and 1 and 10 years of age for cattle.

\section{Study methodology}

\section{Study design and sampling method:}

To estimate the prevalence of the disease a cross-sectional study was conducted. The desired sample size for the study was calculated using Win-Episcope 2,0 computer software program Thrusfield (1995), with 95\% confidence interval and at 5\% absolute Precision. Assuming $42.9 \%$ average prevalence of Fasciolosis for cattle, 50\% for sheep and goats in ELFORA Export Abattoir, a total of 1059 ruminants: 324 cattle, 350 sheep and 385 goats were examined. Data were collected from all study animals for liver and coprological examination and because of the testing capacity of the ELISA kit, we compared the diagnosis results of randomly selected 134 cattle, 68 sheep and 22 goats samples. Each animal was diagnosed against Fasciola infection using serological tests (indirect ELISA), biochemical analysis (serum enzyme GGT and LDH measurements) as well as liver and coprological examination. Animals were tagged on one ear. Blood and fecal samples were collected one day before slaughter. On the next day data was collected from the liver of corresponding ear tagged animal after slaughter.

\section{Fecal egg examination:}

For coprological examination fecal samples were collected from the study animals directly from the rectum. The collected samples were taken to the 
laboratory with tightly closed universal bottles and examined for Fasciola eggs by using simple sedimentation McMaster method as described by Antonia et al (2002).

\section{Postmortem liver examination:}

The liver of each animal was removed and examined for gross pathological lesions, the bile duct and the gall bladder were incised and then the organ was cut to detect immature and adult flukes and to identify the fluke species. Identification of the fluke species involved was carried out by using different parameters such as flukes, cone and shoulder size, shoulder shape and flukes color (Soulsby, 1982). The liver lesion in the acute Fasciolosis is hypertophic and haemeorrhagic, on careful examination, young flukes are found throughout the organ, the peritoneal cavity is infiltrated with a serohemorrhagic fluid and hemorrhagic patches on the peritoneum. In the chronic Fasciolosis the essential lesion is a progressive biliary cirrhosis, hard fibrotic liver in which the bile ducts are prominent, thickened, fibrous and in cattle often calcified and cholangitis with dilated bile ducts containing flukes and their eggs. Eenlargements of the gallbladder and aberrant migration of the flukes is more common in cattle and encapsulated parasites are often seen in the lungs (Soulsby, 1982; Troncy, 1989; Urquhart et al., 1996). The level of pathological lesions within the herd were categorized based on the approach by Ogunrinade and Ogunrinade (1980) as follows; (a) lightly affected if small portion of the organ is affected and only one bile duct is enlarged on the visceral surface of the liver; (b) moderately affected if half of the organ is affected and two or more bile ducts are enlarged and (c) severely affected if most portion of the organ is involved and the liver is cirrhotic.

\section{Liver enzyme assay:}

For enzyme analysis, blood samples were collected using sterile plain vacutainers from the jugular vein of the study animals and the serum separated and kept at- $20^{\circ} \mathrm{C}$ until tested. Serum enzyme activities of LDH and GGT were measured using commercial kits and spectrophotometer according to the kinetic method described by Kerr (2002), in which working reagents were diluted with samples and controls and were preincubated, the photometer was adjusted to 0 absorbance for absorbance reading and for calculating the mean average change in absorbance per minute or the activity of an enzyme analyte. The mean data were interpreted according to the reference interval values indicated for cattle, sheep and goats as 4.9-26, 20-44 and 20-50 for serum 
enzymes GGT and as 309-938, 83-476 and 79-265 for serum enzymes LDH, respectively (Merck, 2006)

\section{Serology for antibody analysis:}

Serum was tested for the presence of Fasciola antibodies against the specific "f2" antigens using Fasciola antigen coated ELISA diagnostic kit as described by Rickard (1995) and Cervi et al (1996). Negative and positive sera were tested in duplicate on antigen pre-coated polystyrene microplates with a total of 45 samples per plate (Institut Pourquier). Controls and serum samples were diluted 1:20 in the ELISA buffer on antigen pre-coated polystyrene micro plates, plates were washed with wash solution 3 times, diluted with the conjugate (an anti-bovine immunoglobulins monoclonal coupled to peroxydase), after a three times washing steps the substrate (TMB) was added to the conjugate, plats were incubated for 20 minutes at $21^{\circ} \mathrm{C}$ away from the light forming a blue compound becoming yellow after blocking. The intensity of the color was a function of the rate of antibodies present in the serum sample. The different classes of seropositivity were determined according to the results obtained from the control sera provided in the kit. The test result was considered reliable when the positive control serum has a minimum uncorrected OD 450 value of 0.350 and a ratio between the corrected OD 450 value of the positive control and uncorrected OD 450 value of the negative control is greater than or equal to 3.5. Reading and interpretation of the corrected optical densities (OD) 450 for each serum sample was done by subtracting the OD 450 value obtained from uncoated well from the OD450 from a coated well and the level of infestation within the herd were determined as listed in the table below (Table 1).

Table 1. Enzyme Linked Immunosorbent Assay test validation and interpretation

\begin{tabular}{ll}
$\begin{array}{l}\text { S/P \% of the sample } \\
\text { Infestation within the herd }\end{array}$ & $\begin{array}{l}\text { results and the level of } \\
\text { correlation between test }\end{array}$ \\
\hline$\% \mathrm{E} / \mathrm{P}>150 \%$ & $+++=$ Strong Infestation \\
& $(>50 \%$ of infestation $)$ \\
& $++=$ Medium Infestation \\
$\mathrm{S} / \mathrm{P}$ included between $80 \%$ and $150 \%$ & (between $20 \%$ and $50 \%$ of infestation) \\
& $+=$ Low Infestation $(<20 \%$ of infestation) \\
$30<\% \mathrm{E} / \mathrm{P}<80 \%$ & $0=$ No infestation \\
$\mathrm{S} / \mathrm{P}<30 \%$ & \\
$\begin{array}{l}\text { S/P (Seropositivity) = corrected OD450 value of the sample / corrected OD } 450 \text { value of the positive control x } \\
100 .\end{array}$ & \\
Source: Institute Pourquier &
\end{tabular}

Ethiop. Vet. J., 2019, 23 (1), 42-58 


\section{Data analysis:}

Data was analyzed using Microsoft Excel spreadsheet for data storage and descriptive statistics. Results of diagnostic techniques were analyzed using WinEpiscope 2.0 software program (2000), testes such as confidence interval and the kappa statistic (agreement among different tests), sensitivity and specificity. Agreement between tests was compared using kappa statistic where the kappa value 0.8-1.0 denotes very good, 0.6-0.8 sustained and 0.4--0.6 moderate (Thrusfield, 1995).

\section{Results}

\section{Coprological study:}

Out of the 324 cattle, 350 sheep and 385 goats slaughtered at ELFORA Export Abattoir, 33\%, 1.14\% and $0.51 \%$ were positive for Fasciola eggs in cattle sheep and goats, respectively (Table 2). Out of the 134 examined cattle 30\% were positive for Fasciola eggs (Figure 4).

Table 2. Prevalence of Fasciolosis in different species of ruminants slaughtered at ELFORA Export Abattoir based on coproscopy.

\begin{tabular}{lccc}
\hline Ruminants & Sample size & Prevalence & $\mathbf{9 5 \%}$ ci \\
\hline Cattle & 324 & $108(33 \%)$ & $28.6-38$ \\
Sheep & 350 & $4(1.14 \%)$ & $0.4-3$ \\
Goat & 385 & $2(0.5 \%)$ & $0.1-2$ \\
\hline
\end{tabular}

\section{Postmortem inspection:}

Out of the 324 cattle, 350 sheep and 385 goats slaughtered at ELFORA Export Abattoir, 38.5\%, 1.14\% and 0.51\%, were found to be positive for lesions of Fasciolosis during postmortem examination, respectively (Table 3). Out of the 134 examined cattle $41 \%$ were positive for lesions of Fasciolosis (Figure 2).

Table 3. Prevalence of Fasciolosis in different species of ruminants slaughtered at ELFORA Export Abattoir based on postmortem inspection.

\begin{tabular}{lccc}
\hline Ruminants & Sample size & Prevalence & $\mathbf{9 5 \% ~ c i ~}$ \\
\hline Cattle & 324 & $125(38.5 \%)$ & $33.6-44.3$ \\
Sheep & 350 & $4(1.14 \%)$ & $0.4-3$ \\
Goat & 385 & $2(0.5 \%)$ & $0.1-2$ \\
\hline
\end{tabular}


Based on the classification of liver pathology, from the 54 out of 134 infected cattle livers, $31(23 \%)$ of the livers were lightly infected, 20(15\%) moderately infected and 3(2.2\%) were severely damaged (Figure 1).

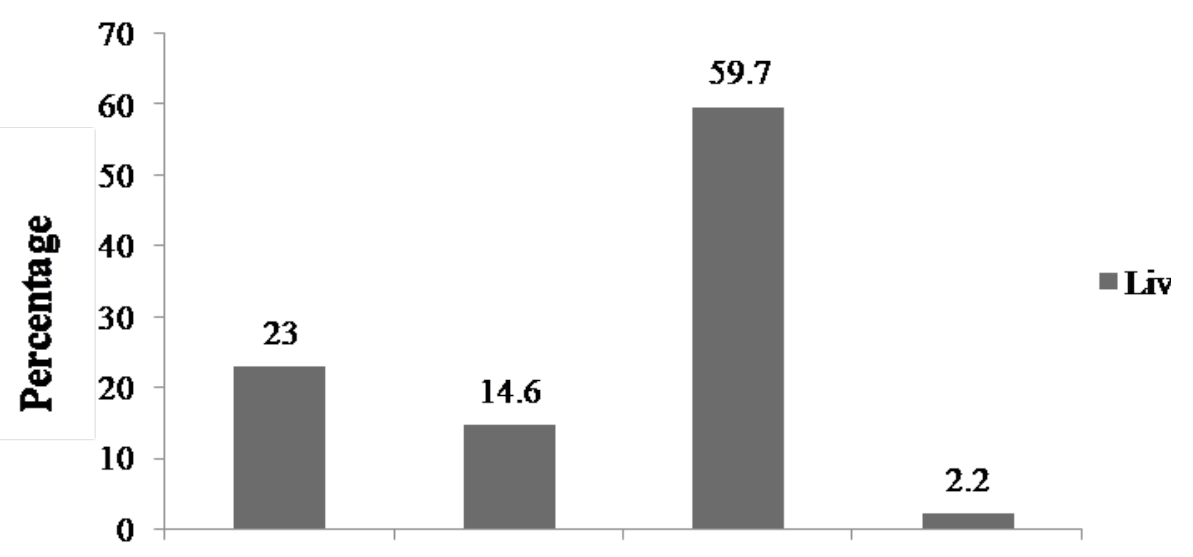

Figure 1. Classification of liver pathology

Serum enzyme analysis: Out of 134 examined cattle for of GGT and LDH, $42 \%$ and $75 \%$ of the samples had an increased level of GGT and LDH, above the normal values, respectively (Figure 2).

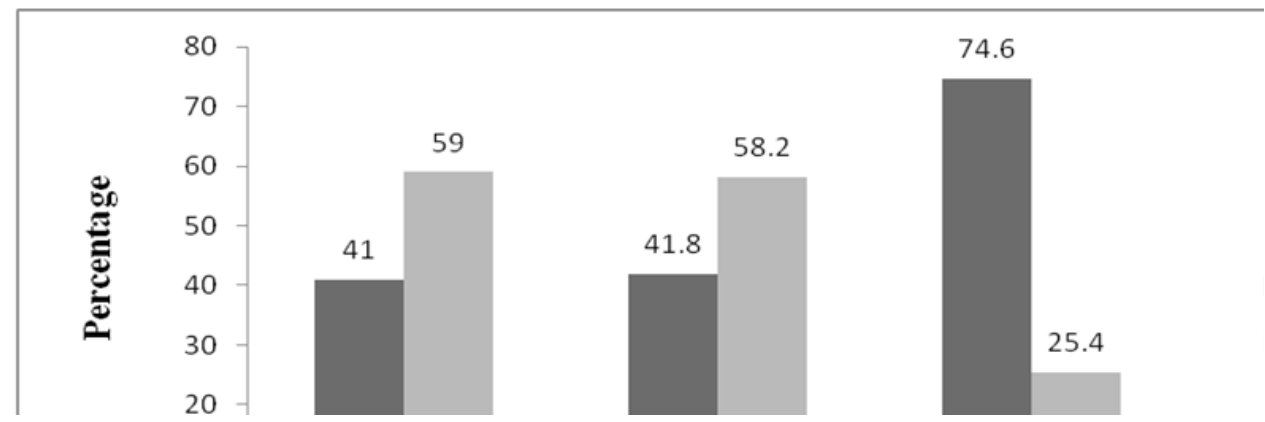

Figure 2. Comparison of enzyme activities and liver pathology in cattle 


\section{Serological examination (indirect ELISA):}

Out of the 134 cattle serum analyzed, $75 \%$ of the samples were found to be positive for antibodies against Fasciola specific f2 antigens. Based on antibody detection ELISA against Fasciola specific $\mathrm{f} 2$ antigens, the levels of infestation, from the 100 out of 134 antibody positive samples against Fasciola specific f2 antigens, $23 \%$ of the animals were lightly infected, $48 \%$ were moderately infected and 1.5\% were severely infected (Figure 3 and 4). The sensitivity and specificity of ELISA were $100 \%$ and $42.5 \%$ respectively.

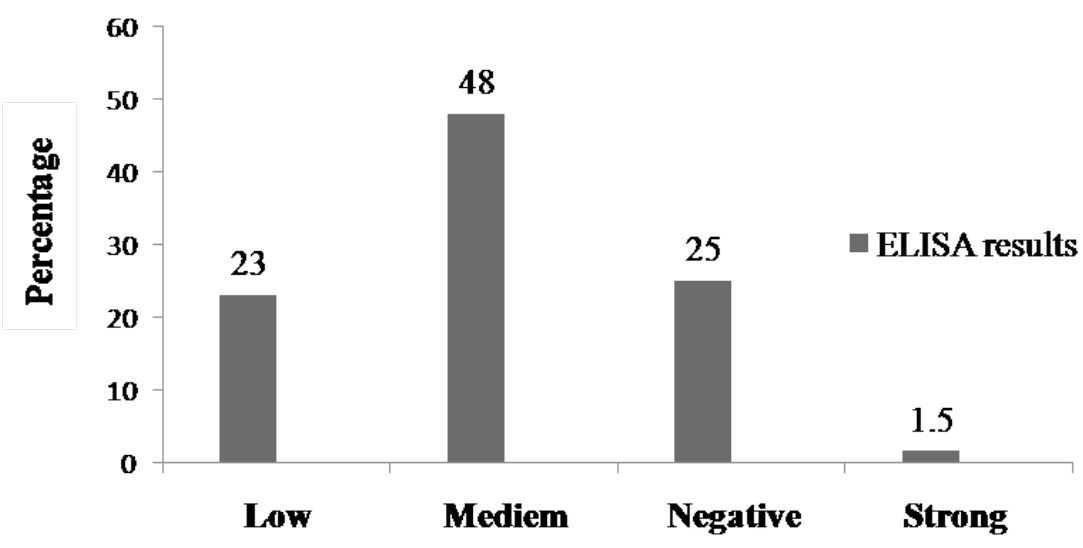

Figure 3. ELISA results and level of infestation within the herd

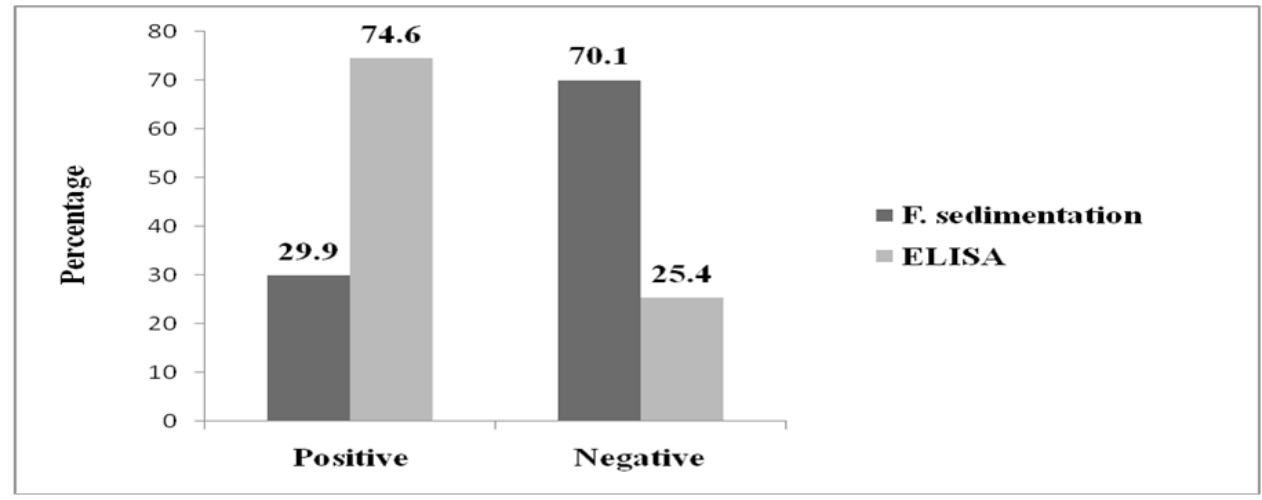

Figure 4. Comparison of ELISA and fecal sedimentation results 


\section{Comparative results of different diagnostic tests:}

Summary results of the different diagnostic test employed on 134 cattle and the statistical analysis results are presented in (Table 4). There was a strong relationship between fecal examination and postmortem findings of liver lesions, with Kappa value, (Kappa $=0.758)$. Test agreement between postmortem findings of liver lesions and ELISA (Kappa=0.373) and between postmortem findings of liver lesions and serum enzyme activities of GGT (Kappa=0.332) is moderate, the relationship between fecal examination and ELISA (Kappa= 0.236) is weak and agreement between postmortem findings of liver lesions and serum enzyme activities of LDH is absent (Kappa $=-0.066)$.

Table 4. Comparison of the different diagnostic methods in relation to the results of coproscopy and postmortem examination

\begin{tabular}{|c|c|c|c|c|c|c|c|c|c|}
\hline \multirow{2}{*}{ Factor } & & \multicolumn{2}{|l|}{ ELISA } & \multicolumn{2}{|l|}{ GGT } & \multicolumn{2}{|l|}{ LDH } & \multicolumn{2}{|l|}{ PMI } \\
\hline & & $\begin{array}{l}\text { Nega- } \\
\text { tive }\end{array}$ & $\begin{array}{l}\text { Posit- } \\
\text { ive }\end{array}$ & $\begin{array}{l}\text { Nega- } \\
\text { tive }\end{array}$ & $\begin{array}{l}\text { Posit } \\
\text { ive }\end{array}$ & $\begin{array}{l}\text { Nega } \\
\text { tive }\end{array}$ & $\begin{array}{l}\text { Posit } \\
\text { ive }\end{array}$ & $\begin{array}{l}\text { Nega } \\
\text { tive }\end{array}$ & $\begin{array}{l}\text { Posit } \\
\text { ive }\end{array}$ \\
\hline \multirow{3}{*}{$\begin{array}{l}\text { Fecal exami- } \\
\text { nation }\end{array}$} & Negative & 33 & 60 & 63 & 29 & 21 & 71 & 79 & 14 \\
\hline & Positive & 1 & 40 & 15 & 26 & 10 & 31 & 1 & 40 \\
\hline & $\begin{array}{l}\text { Kappa } \\
\text { test }\end{array}$ & \multicolumn{2}{|c|}{0.236} & \multicolumn{2}{|c|}{0.291} & \multicolumn{2}{|c|}{-0.011} & \multicolumn{2}{|c|}{0.758} \\
\hline \multirow{3}{*}{$\begin{array}{l}\text { Liver Exami- } \\
\text { nation (PMI) }\end{array}$} & Negative & 34 & 46 & 57 & 22 & 16 & 63 & & \\
\hline & Positive & 0 & 54 & 21 & 33 & 15 & 39 & & \\
\hline & $\begin{array}{l}\text { Kappa } \\
\text { test }\end{array}$ & \multicolumn{2}{|c|}{0.373} & \multicolumn{2}{|c|}{0.332} & \multicolumn{2}{|c|}{-0.066} & & \\
\hline
\end{tabular}

\section{Discussion}

In the present finding, the overall prevalence of cattle Fasciolosis based on coproscopy (33\%) and postmortem examination (38.5\%) is comparable with the results of many authors in various parts of Ethiopia (Getu, 1987; Wondwosen, 1990; Rahmeto, 1992; Adem, 1994; Abduljebar, 1994; Hailu, 1995; Mesfin, 1999). The overall prevalence of small ruminant Fasciolosis, resulting from coproscopy and postmortem examination was $0.5 \%$ in goats and $1.14 \%$ in sheep. The present finding is by far lower than the abattoir survey report of Daniel (1995), who reported 14.8\% of ovine Fasciolosis in Dire Dawa and Rahmeto (1992), who reported $12.4 \%$ of caprine Fasciolosis in Wolliso. The lower prevalence of Fasciolsis reported using coproscopy in bovine (30\%) compared to post mortem finding (41\%), indicates the less sensitivity of the test in de- 
tecting the actual presence of the disease. According to Abduljebar (1994), the prevalence of Fasciolosis by coproscopy was $34 \%$ while $49 \%$ by post mortem examination; the sensitivity of sedimentation technique in detecting Fasciola infection is about 33\% while Sisay and Nibret (2013), reported much better, $69.5 \%$ sensitivity. A longer period from 8-15 weeks after infection is needed for the appearance of Fasciola eggs in the feces (Hillyer, 1999; O'Neill et al., 2000; Cornelissena et al., 2001; Sanchez-Andrade et al., 2002). Furthermore, detection of Fasciola eggs and diagnosis of the disease in some cases is difficult during the patent period because eggs are expelled intermittently depending on the evacuation of the gall bladder and the biology of the Fasciola (Troncy, 1989). In the current study, the higher prevalence of Fasciolsis reported using indirect ELISA method in bovine (75\%) compared to post mortem finding (41\%), and to coproscopy (30\%), indicates the high sensitivity of ELISA (100\%) in diagnosing fasciolosis.

The overall assessment indicates the relatedness of ELISA findings with postmortem findings of liver lesions and fecal examination results. Our finding in cattle is in agreement with Hillyer et al (1996), who tested 147 cattle and found that 38 of the cattle were positive parasitologically while 84 were positive serologically with $82 \%$ sensitivity. The immunoenzymatic techniques such as indirect ELISA have been found to be very suitable for the diagnosis of Fasciolosis due to their high sensitivity and the possibility of processing many sera samples (Arriaga et al., 1989). Martinez et al (1996) and Hillyer (1999), also indicated that these techniques are important for the diagnosis of fasciolosis because of an earlier detection than coproscopic is allowed. Ibarra et al (1998), were able to compare the sensitivity, specificity and usefulness of the DIG-ELISA, DOT-ELISA and indirect ELISA tests for determining the seroprevalence of Fasciolosis in cattle under tropical conditions in Mexico and they found that indirect ELISA yielded the highest level of IgG and $F$. hepatica antibodies with a sensitivity of $97 \%$ and specificity of $98.8 \%$ than Dig ELISA 97.5\% and 80.0\% and Dot ELISA 93.1\% and 95.4\%, respectively.

In the present study, Out of 80 cattle, which were negative for lesions of Fasciola, 46 of them had antibodies against F2 antigens of $F$. hepatica. Animals with no detectable liver lesions but positive for serology might have been at their early stage of invasion with immature flukes. However, the presence of antibodies does not always correlate to active Fasciolosis because antibody levels diminish slowly after cure and remains positive for 5 months after treatment with or without the presence of liver flukes (Hillyer, 1999; Sanchez-Andrade et al., 
2002). By means of the indirect ELISA, based on excretory, secretory antigen, it has been also possible to detect experimental Fasciola infections in cattle from the third to the fifth week after infection during the liver migratory phase of immature worms María Soledad (1992) on the other hand, a longer period is required to detected positive animals through fecal examination. Cornelissen et al (2001), were able to detect positive animals by egg count only from week 9 in sheep and even later in cattle from week 15 onwards after natural infection of animals with F. hepatica, and Arias et al (2005), in their experimental work have detected positive animals through fecal examination 11 weeks after primary infection. Perez et al (2005), reported that eggs in stools indicates the presence of mature adult flukes in the bile ducts and gallbladder, but a period longer than 10 weeks after infection is required so most of the pathological damage has already occurred. The classification of liver pathology and the level of Fasciola infestation within the herd were compared based on postmortem findings of liver lesions and antibody detection by ELISA, the results of light and sever infection were similar, $23 \%$ and $2 \%$ of the animals were lightly and severely infected respectively, in both tests. However, 48\% and $15 \%$ of the animals were moderately infected based on ELISA and liver lesions of Fasciola, respectively this indicates the high sensitivity of ELISA in diagnosing Fasciolosis.

Contrary to the findings obtained in cattle, the overall finding regarding Fasciolosis in small ruminants was low both through the standard fecal sedimentation techniques and ELISA. Out of the randomly selected 68 sheep only 1 was positive parasitologically and 3 were positive serologically and of 22 goats tested, 1 was positive parasitologically and serologically. These findings generally suggest the very low prevalence of Fasciolosis in small ruminants. This perhaps related to the origin of the animals. Almost all small ruminants slaughtered originate from the mid and lowland parts of the eastern Ethiopia, areas most of the time considered to be low risk areas for $F$. hepatica infection due to the arid or semiarid ecology. Fasciola hepatica was shown to be the most important fluke species in Ethiopian livestock with distribution over three-quarter of the nation except in the arid north-east and east of the county while the distribution of $F$. gigantica was mainly localized in the western humid zone of the country that encompasses approximately one fourth of the nation (Malone et al., 1998; Yilma \& Malone, 1998).

Changes in serum enzymes are indicators of hepatic metabolism impairment (Galtier et al., 1994; Ferre et al., 1996). Certain tissue cells contain characteristic enzymes, which enter the blood only when the cells to which they are 
confined are damaged or destroyed. The presence in the blood of significant quantities of these specific enzymes indicates the probable site of tissue damage. The level of GGT rise dramatically with obstructive diseases of the biliary tract and liver cancers and is especially useful in assessing liver function associated with liver disease (Ramnic, 1999; Charles, 2003; Merck, 2006). In support of the above statement, our findings regarding the level of GGT that $42 \%$ of the samples had an increased level of serum enzyme GGT suggest its association with liver lesions resulted at postmortem examination on $41 \%$ of cattle. The test of agreement between the liver examination and GGT determination was however moderate. Out of the 54 cattle with known liver lesions of Fasciola, 33 of them were having elevated levels of GGT than normal value for cattle. As the same time, out of the 79 cattle without liver lesions of Fasciola, 22 of them were having elevated levels of GGT than normal value for cattle. This might indicate increased levels of GGT could be yielded due to other liver diseases with or without the presence of Fasciolosis. The level of LDH has shown to be generally elevated both in negative as well as positive animals for liver lesions indicating the absence of agreement between liver lesions and level of LDH. Seventy five percent of the examined cattle had elevated levels of LDH in their serum. LDH modification indicates mostly a cell necrosis during migration of young flukes through the liver parenchyma. $\mathrm{LDH}$ provide information on the passage of young flukes through the liver parenchyma (Charles, 2003), while GGT would be more associated with bile duct damages. GGT increase indicates penetration of the bile ducts by flukes, causing a hyperplastic cholangitis (Galtier et al., 1986; Ferre et al.,1994; 1995a; 1995b; 1996; 1997). Lactic Dehydrogenase (LDH -5) is useful in assessing acute, ongoing liver disease and neither is usually increased in chronic liver disease. LDH-5 can also caused by hepatocellular disease, in addition none of the common tests (bilirubin, GGT, GLDH, AP, LDH, AST, or alanine transaminase) for liver damage or function are clinically useful for detection of hepatic disease when used alone (Ramnic, 1999; Merck, 2006). Serum concentrations of liver-specific enzymes are generally higher in acute liver disease than in chronic liver disease. They may be within normal limits in the later stages of sub acute or chronic hepatic disease (Merck, 2006). In addition, these enzymes are also produced by a variety of other tissue and organ cells and hence results should be interpreted in conjunction with other diagnostic tests.

In conclusion, coprological examination for parasite eggs has significant limitations in detecting Fasciolosis. Cattle, which were negative for liver lesions of Fasciola and for Fasciola eggs at coproscopy, were having antibodies against Fasciola specific antigens. ELISA method is a good diagnostic tool and may allow early detection of disease. Measurement of hepatic enzymes such as GGT 
and LDH are supportive indicators in the diagnosis of Fasciolosis. There was a strong relationship in the diagnosis of Fasciolosis between fecal examination and findings of liver lesions. The test agreement between ELISA findings and the results of fecal examination is weak, the relationship between ELISA findings and examination of liver lesions and between serum enzyme GGT activities and the findings of liver lesions is moderate and the relationship between liver lesions and level of LDH is absent. Coprological examination should be repeated and supported by other diagnostic methods for better diagnostic techniques and to recommend appropriate drugs and timely intervention. Enzyme analysis needs to be done to know the degree of hepatic damage.

\section{Acknowledgements}

Authors would like to thank the Elfora export abattoir for providing data for the study purpose, Addis Ababa University, Faculty of Veterinary Medicine for financial support, The National Veterinary Institute and the technical staffs for their support in allowing us to use their laboratory. We thank the Institute of Pourquier, France for providing us the Fasciola ELISA kit for free of charge.

\section{Conflict of interest}

There is no conflict of interest to declare

\section{References}

Abdul, J. R., 1992. Economic significance of bovine fasciolosis and Hydatidiosis in Soddo. Addis Ababa University, Faculty of Veterinary Medicine, Debre Zeit, Ethiopia, DVM Thesis.

Abduljebar, M., 1994. Prevalence and economic significance of bovine Fasciolosis in Sinana District, Bale-Region. Addis Ababa University, Faculty of Veterinary Medicine, Debre Zeit, Ethiopia, DVM Thesis.

Abera, B., 1990. Prevalence and economic significance of Fasciolosis in "Neur cattle" slaughtered at Dembi-Dollo slaughter house. Addis Ababa University, Faculty of Veterinary Medicine, Debre Zeit, Ethiopia, DVM Thesis.

Adem, A., 1994. Prevalence of bovine and ovine Fasciolosis: A preliminary survey around Ziway Region (Shewa). Addis Ababa University, Faculty of Veterinary Medicine, Debre Zeit, Ethiopia, DVM Thesis.

Ethiop. Vet. J., 2019, 23 (1), 42-58 
Antonia, M., Conceiçao, P., Rute, M., Durao, Isabel, H., Costa, Jose., Correia de Costa., 2002. Evaluation of a simple sedimentation method (modified MacMaster) for diagnosis of bovine Fasciolosis. Vet. Parasitol., 105(4), 337-343. https://doi.org/10.1016/ S0304-4017(02)00016-X.

Arias, M., Hillyer, G.V., Sanchez-Andrade, R., Suarez, J.L., Pedreira, J., Lomba, G., Diaz, P., Morrondo, P., Diez-Banos, P., Paz-Silva, A., 2005. A 2.9KDA Fasciola hepatica recombinant protein-based ELISA test for the detection of current ovine Fasciolosis trickle infected. Vet. Parasitol., 137(1-2), 67-73. https://doi.org/10.1016/j. vetpar.2005.12.015.

Arriaga, de M. C., Paniagua, R. Ruiz., Navarrete, A., Bautista, C. R., Morilla, A., 1989. Comparison of dot Enzyme Linked Immunosorbent Assay (dot-elisa), passive haemaglutination test (pht) and thin layer immunoassay (tia) in the diagnosis of natural or experimental F. hepatica infections in sheep. Vet. parasitol., 30 (3), 197-203. https://doi.org/10.1016/0304-4017(89)90015-0.

Cervi, L., Rubinsteni, H and Masih, D. T., 1996. Involvement of excretion-secretion products from Fasciola hepatica inducing suppression of the cellular immune responses. Cordova, Argentina. Vet. Parasito., 61(1-2), 97-111. https://doi. org/10.1016/0304-4017(95)00816-0.

Charles, E. Ophard., 2003. Diagnostic serum enzymes review. Elmhurst College. Virtual Chembook. http://www.hendrickhealth.org/healthy/000804.htm.

Cornelissena, Jan. B., Cor, W. J., Gaasenbeeka, P., Fred, P. H., Borgsteedea, H.M., Wicher, G., Holland, b.C., Michiel, M., Harmsena, Wim., Boersm, J.A., 2001. Early immunodiagnosis of fasciolosis in ruminants using recombinant Fasciola hepatica cathepsin L-like proteaseq. Int. J. parasitol., 31(7), 728-737. https://doi. org/10.1016/S0020-7519(01)00175-8.

Dagne, M., 1994. Survey on prevalence and economic significance of Bovine Fasciolosis in Debre Berhan region. Addis Ababa University, Faculty of Veterinary Medicine, Debre Zeit, Ethiopia, DVM thesis.

Daniel, F., 1995. Economic importance of organs condemnation due to Fasciolosis and Hydatidosis in cattle and sheep slaughtered at Dire Dawa Abattoir. Addis Ababa University, Faculty of Veterinary Medicine, Debre Zeit, Ethiopia, DVM thesis.

Ferre, I., Barrio, J.P., Gonzalez-Gallego, J., Rojo-Vazquez, F. A., 1994. Appetite depression in sheep experimentally infected with Fasciola hepatica. Vet. Parasitol., 55(12), 71-79. https://doi.org/10.1016/0304-4017(94)90056-6.

Ferre, I., Lopez, P., Gonzalo-Orden, M., Julian, M. D., Rojo, F. A., Gonzalez-Gallego, J., 1995a. The effects of subclinical fasciolosis on hepatic secretory function in sheep. Parasitol. Res., 81(2), 127-131. 
Ferre, I., Lopez, P., Rojo-Vazquez, F., Gonzalez-Gallego, J., 1996. Experimental ovine fasciolosis: Antipyrine clearance as indicator of liver damage. Vet. Parasitol., 62 (1-2), 93-100. https://doi.org/10.1016/0304-4017(95)00857-8.

Ferre, I., Ortega-Mora, L.M., Rojo-Vazquez, F.A., 1995b. Seroprevalence of Fasciola hepatica infection in sheep in northwestern Spain. Parasitol. Res., 81(2), 137-142.

Ferre, I., Ortega-Mora, L., Rojo-Vazquez, F.A., 1997. Serum and Bile antibodies responses (IgG and IgA) during sub clinical Fasciola hepatica infection in sheep. Vet. Parasitol., 68(3), 261-267. https://doi.org/10.1016/S0304-4017(96)01070-9.

Galtier, P. L. G., Tufenkji, A. E., Franc, M., 1986. Incidence of experimental fascioliasis, on the activitiy of drug metabolizing enzymes in lamb liver. Drug metab. Dispos., 14(1), 137-141.

Galtier, P., Coulet, M., Sutra, J.F. Biro., Souvour, B., Aluinerie, M., 1994. Fasciola hepatica: Mebendazole and Thiabendazole pharmacokinetics in sheep. Parasitol., 79(2),166-176. https://doi.org/10.1006/expr.1994.1076.

Getu, D., 1987. A study on the Incidence and Economic Significance of fasciolasis in Woliata Awraja. Addis Ababa University, Faculty of Veterinary Medicine, Debre Zeit, Ethiopia, DVM thesis.

Gonenc, B., Sarimehmetoglu, H.O., Kara, M., Kircali, F., 2004. Comparison of crude and excretory/secretory antigens for the diagnosis of Fasciola hepatica in sheep by western blotting. Turk. J. Vet Animal Sci., 28, 943-949.

Hailu, D., 1995. Bovine fascioliosis at Awassa municipal slaughter house prevalence and economic loss. Addis Ababa University, Faculty of Veterinary Medicine, Debre Zeit, Ethiopia, DVM thesis.

Hillyer, G. V., 1999. Immuno diagnosis of human and animal Fascilosis. In: Dalton, J. (Ed), Fasciolosis ,13. CAB international, Pp. 435-447.

Hillyer, G.V., Soler de Galanes, M., Buchon, P., Buorland, J., 1996. Herd evaluation by enzyme-linked immunosorbent assay for the determination of Fasciola hepatica infection in sheep and cattle from the Altiplano of Bolivia. Vet. Parasitol., 61(3-4), 211-220. https://doi.org/10.1016/0304-4017(95)00831-4.

Ibarra, F., Montenegro, N., Vera, Y., Boulard, C., Quiroz, H., Flores, J., Ochoa, P., 1998. Comparison of Three ELISA tests for Seroepidemiology of bovine fascioliosis. Vet. Parasitol., 77(4), 229-236. https://doi.org/10.1016/S0304-4017(98)00111-3.

Kerr, M.G., 2002. Clinical enzymology-plasma enzymes in diagnosis, pp: 135-296. In: M.G. Kerr, (ed.). Veterinary Laboratory Medicine (Clinical Biochemistry and Haematology). $2^{\text {nd }}$ ed., Blackwell Science. London, United Kingdom. 
Malone, J.B., Gommes, R., Hansen, J., Yilma, J.M., Slingenberg, J., Snijders, F., Nachet, O. F. and Ataman, E., 1998. A Geographic information system on the potential distribution and abundance of Fasciola hepatica and F. gigantica in East Africa based on Food and Agriculture Organization databases. Vet. Parasitol., 78(2), 87-101. https://doi.org/10.1016/S0304-4017(98)00137-X.

María Soledad, M.G., 1992. Epizootiologia de la Fasciolosis bovina en Asturias: Identificación y expresión de un antigeno unitario Universidad de Oviedo, Facultad de Biologia, $\mathrm{PhD}$ Tesis. https://www.educacion.gob.es/t.

Martinez, A., Martinez-Cruz, M.S., Martinez, F.G., Gutierrez, P.N., and Hernandez, S., 1996. Detection of antibodies to Fasciola hepatica excretory-secretory antigens in experimentally infected goats by Enzyme Immunosorbent Assay. Vet. Parasitol., 62(3-4), 247-252. https://doi.org/10.1016/0304-4017(95)00876-4.

Merck., 2006. Merck Veterinary manual, 9th Edition, Merck and Co. Inc, Whitehouse Station., NJ, USA.

Mesfin, A. Y., 1999. Study on the prevalence of bovine Fasciolosis and morphometric analysis of liver fluke population in North Gondar area, Ethiopia. Addis Ababa University, Faculty of Veterinary Medicine, Debre Zeit, Ethiopia. DVM Thesis.

O’Neill, S.M., Brady, M.T., Callaghan, J.J., Mulcahy, G., Joyce, P., Mills, K. H.G., and Dalton, J.P., 2000. Fasciola hepatica infection down regulates th1 responses in mice. Parasite Immunol., 22(3),147-155. doi.org/10.1046/j.1365-3024.2000.00290.x.

Ogunrinade, A., and Ogunrinade B., 1980. Economic importance of Bovine Fasciolosis in Nigeria, Trop. Anim. Health Prod., 12 (3). 155-160.

Perez, J., Ortega, J., Bravo, A., Diez-Banos, P., Morrondo, P., Moreno, T., and MartinezMoreno, A., 2005. Phenotype of hepatic infiltrates and hepatic lymph nodes of lamb primarily and challenge infected with Fasciola hepatica, with and without triclabendazole treatment. Vet. Res., 36(1), 1-12. doi.org/10.1051/vetres:2004047.

Rahmeto, A., 1992. Fasciolosis clinical occurrences, coprological, abattoir and snail survey in and around Wolisso. Addis Ababa University, Faculty of Veterinary Medicine, Debre Zeit, Ethiopia. DVM Thesis.

Ramnic Sood., 1999. Medical Laboratory Technology Methods and Interpretations $5^{\text {th }}$ ed.. Jaypee Brothers Medical Pub.New Delhi, India. Pp 480-529.

Rickard, L.G., 1995. Development and application of a dot- ELISA test for the detection of serum antibodies to Fasciola hepatica antigens in llamas. Vet Parasitol., 58(1-2), 9-15. doi.org/10.1016/0304-4017(94)00709-L.

Sanchez-Andrade Fernandez, R., Morrondo Pelayo, P., Lopez Sandez, C., Panadero Fontan R., Diez Banos P.,1995. Evaluation of Fasciola hepatica infection preva- 
lence in cattle in Galicia (north west Spain) by enzyme linked immunosorbent assay. Res. Rev. parasitol., 55 (2), 103-107.

Sanchez-Andrade, R., Paz-Silva A., Suarez, J.L., Pandero, R., Pedreira, J., Lopez, C., Diez-Banos, P., and Morrondo, P., 2002. Influence of age and breed on natural bovine Fasciolosis in an endemic area (Galicia, NW Spain). Vet. Res. Commun., 26(5), 361-370.

Sisay, A., and Nibret, E., 2013. Prevalence and risk factors of bovine and ovine Fasciolosis, and evaluation of direct sedimentation sensitivity method at Bahir-Dar Municipal Abattoir, Northern Ethiopia. Ethiop.Vet.J., 17(2), 1-17. dx.doi.org/10.4314/ evj.v17i2.1.

Soulsby, E.J.L., 1982. Helminthes, arthropods and protozoa of domesticated animals, $7^{\text {th }}$ Ed. Baillière Tindall, London, UK, Pp.40-52.

Thrusfield, M., 1995. Veterinary Epidemiology $2^{\text {nd }}$ edition, University of Edinburgh,

Blackwell Science Ltd., UK. Pp.180-188.

Troncy, P.M., 1989. Helminths of livestock and poultry in Tropical Africa. In: Fischer. 1989. Manual of tropical veterinary parasitology. CAB International, UK. Pp. 63 73.

Urquhart, G.M., Duncan, J.L., Armour, J., Dunn., Jenning A.M., 1996. Veterinary parasitology. $2^{\text {nd }}$ Edition. Blacwell Scince, Ltd., UK. Pp. 103-113.

Wondwosen, A., 1990. Prevalence of bovine Fasciolosis in Arsi administrative region. Addis Ababa University, Faculty of Veterinary Medicine, Debre Zeit, Ethiopia, DVM Thesis.

Yilma, J.M., and Malone, J.B., 1998. A geographic information system forecast model for strategic control of fasciolasis in Ethiopia. Vet. Parasitol., 78 (2), 103-123. doi. org/10.1016/S0304-4017(98)00136-8

Zewdu, B., 1991. Prevalence and economic analysis of liver fluke infestation in cattle slaughtered at Jimma Municipal Abattoir. Addis Ababa University, Faculty of Veterinary Medicine, Debre Zeit, Ethiopia, DVM Thesis. 